\title{
Athletic Training: From Physical Education to Allied Health
}

\section{David H. Perrin}

Perrin, DH. (2007). Athletic training: From physical education to allied health. QUEST (Invited Paper), 59:111-123.

\section{***Note: Figures may be missing from this format of the document}

\begin{abstract}
:
Athletic training was spawned from physical education in the 1960s, and since that time has evolved into a recognized health care profession. The majority of accredited athletic training education programs (ATEPs) are housed within academic units of kinesiology. However, the National Athletic Trainers' Association (NATA) has recommended that ATEPs be aligned in colleges of health-related professions. To set some context for the issue, this paper will review the history and evolution of athletic training education. NATA's rationale for alignment of ATEPs with the health-related professions will be presented, and the implications of this potential transition for kinesiology will be addressed. Finally, the challenges kinesiology administrators and faculty face in offering and retaining accredited ATEPs will be explored.
\end{abstract}

Article:

The National Athletic Trainers' Association (NATA) was founded in 1950 at a meeting attended by about 200 men in Kansas City (http://www.nata.org/about_NATA/history.htm). Since that time the profession has grown to nearly 29,500 total members, over 24,400 certified members (http://www.nata.org/membership/ MembStats/2006_09.htm), and women comprise approximately half of the certified membership. The mission of the NATA is to enhance the quality of health care provided by certified athletic trainers and to advance the athletic training profession (http://www.nata.org/about_NATA/mission.htm). Certified athletic trainers (ATC) are health care providers who specialize in the prevention, assessment, treatment, and rehabilitation of injuries and illnesses (http://www.nata.org/about_AT/terminology.htm).

The profession has also made great strides in professional education, and has grown from four NATA “approved” undergraduate athletic training education programs (ATEPs) in 1969 to 352 entry-level programs accredited by the Commission on Accreditation of Athletic Training Education (CAATE) today. An additional 13 post-certification master's degree academic programs are accredited by the NATA, and at least 12 universities market doctoral programs tailored for certified athletic trainers (Table 1). William E. (Pinky) Newell, the father of modern day athletic training, would probably have never imagined the growth that the profession would experience during the three decades that followed. Likewise, few athletic training educators would have imagined that in 2006 the suggested move to academic units

Table 1 List of Institutions Currently Offering Doctoral Programs Tailored for Certified Athletic Trainers

Indiana State University

Oregon State University

Temple University 
University of Florida

University of Kentucky

University of North Carolina at Chapel Hill University of North

Carolina at Greensboro University of Oregon

University of Pittsburgh

University of Toledo

University of Virginia

Virginia Commonwealth University

From Arnold, Gansneder, Perrin (2005): Research Methods in Athletic Training.

of health-related professions would be among the recommendations for athletic training education reform.

Athletic training education programs were originally spawned from departments of physical education. Included among the schools or colleges that now house ATEPs are HPER (health, physical education, and recreation), education, arts and sciences, professional studies, allied health or rehabilitation sciences, and others. Examples of the academic departments that offer accredited ATEPs include athletic training, education, health sciences, kinesiology, natural sciences, and others. In 1997, the NATA recommended that "The NATA should encourage new athletic training education programs to consider aligning themselves in colleges of health-related professions.” (NATA Education Task Force, 1997). Information related to the academic affiliation and administrative home for accredited athletic training education programs is currently unavailable from the CAATE. However, a current study examining academic role strain among athletic training educators found approximately $70 \%$ of ATEPs remain housed within departments affiliated with kinesiology and/or the subdisciplines of human performance (Charles-Liscombe, 2007).

Administrators of academic units of kinesiology face a host of challenges in offering and retaining ATEPs. These include accreditation standards that demand additional resources, the NATA's recommendation that ATEPs align themselves with academic units of allied health, and an NATA mandate for a degree in athletic training no later than the 2014-2015 academic year. The following sections will review the history and evolution of athletic training education, the impact of expanded accreditation requirements on education of athletic training students, and will explore if ATEPs belong in academic units of kinesiology or allied health.

\section{History of Athletic Training Education}

In commemoration of the 50th year celebration of the athletic training profession, Delforge and Behnke (1999) wrote what remains the most comprehensive treatise on the history and evolution of athletic training education. The authors explained that under the visionary leadership of William Newell, the genesis of athletic training education occurred in 1955 with the appointment of the NATA Committee on Gaining Recognition (Table 2).

TABLE 2 IS OMITTED FROM THIS FORMATTED DOCUMENT 
The first athletic training curriculum model was approved by the NATA in 1959, and included physical therapy school prerequisites, a set of specific required courses, and several recommended courses (Table 3). Examination of this model reveals what was essentially a physical education curriculum with the addition of two professional courses in athletic training, Techniques of Athletic Training and Advanced Techniques of Athletic Training, and laboratory practices in athletic training. The primary features of the original model were an emphasis on attainment of a secondary-level teaching credential and preparation of students for positions as physical education/health teacher-athletic trainers. It is also relevant that the practice settings for athletic trainers at that point in time were almost exclusively with scholastic, college/university, and professional sports.

\section{TABLE 3 IS OMITTED FROM THIS FORMATTED DOCUMENT}

In 1968, the NATA conducted a survey of physical education directors/heads to assess their level of understanding of the 1959 curriculum model (Miller, 1999, 1970). The survey also sought to determine if athletic training curricula were currently being offered, and to project the potential development of additional athletic training education programs. Less than half of the directors/heads had knowledge of the 1959 curriculum model, yet 19 indicated they offered a curriculum in athletic training and another 23 indicated their intention to develop a curriculum in the future. Consequently, 42 institutions were invited to submit their academic programs in athletic training for initial NATA approval. Four institutions immediately submitted applications for curriculum approval, and became the first NATA-approved athletic training education programs. These institutions were Indiana State University, Lamar Tech, Mankato State College, and New Mexico University.

In 1970, the NATA began the process of certifying athletic trainers through a written and practical examination. Later that same decade, a proliferation of NATA approved ATEPs was seen, and a revised athletic training curriculum model was developed (Table 4). The rationale for the revised model was an insufficient market for high school physical education/health teacherathletic trainers and the perception that the inclusion of prerequisites in the curriculum for admission to physical therapy school was unnecessary. The curriculum was not substantially different in athletic training core content from the 1959 model, but did require laboratory or practical experience under the direct supervision of a certified athletic trainer.

\section{TABLE 4 IS OMITTED FROM THIS FORMATTED DOCUMENT}

Another watershed event in athletic training professional education occurred in 1980 with the NATA resolution to require an athletic training major, or equivalent, by 1986. The 1983 edition of the Guidelines for Development and Implementation of NATA Approved Undergraduate Athletic Training Education Programs stated that the ATEP “...shall be designed so as to constitute an academic major or the equivalent of a major.” The guidelines further stated that “...the athletic training curriculum may be developed as a major degree program leading to a bachelor's degree in athletic training or as the equivalent of an athletic training major within an existing degree program.” Regardless of the type of degree program, the guidelines stated that the ATEP must involve a course of study which is “....at least equivalent to the minimum number of semester/quarter hours which constitute an academic major in the educational unit in which 
the athletic training education program is housed....” The primary features of the 1983 Guidelines for an Athletic Training Major included the transition from specific courses to subject matter requirements (Table 5), and replacement of behavioral objectives with Competencies in Athletic Training based on performance domains identified from the NATA's first professional role delineation study.

In the late 1980s, work began to transition the NATA “approval” process to one of accreditation of ATEPs by the American Medical Association's (AMA) Committee on Allied Health Education and Accreditation (CAHEA). Part and parcel to this transition was the need for the athletic training profession to be formally recognized as an allied health profession by the AMA, and this recognition occurred in 1990. In 1991, the Essentials and Guidelines for an Accredited Educational Program for the Athletic Trainer was approved by the AMA Council on Medical Education, and the first entry-level ATEP was accredited by CAHEA in 1994. The Essentials and Guidelines also encouraged clinical education opportunities in "non-traditional” athletic training settings such as sports medicine clinics, physician's offices, and other allied health practice settings. These events may have planted the initial seeds that led to the 1997 recommendation that athletic training education programs consider aligning themselves in colleges of health-related professions.

In 1994 the NATA Education Task Force was appointed and charged with reviewing all aspects of undergraduate and graduate education. The recommendations of the Task Force were adopted by the NATA Board of Directors in 1996 (NATA Education Task Force, 1997). Among the 18 provisions recommended by the Task Force were two that related to the NATA's interest in positioning its academic programs with allied health. Provision 11 stated "The NATA should encourage the development of multi-disciplinary education programs that coordinate athletic training with teaching, nursing, physical therapy, occupational therapy, or other appropriate baccalaureate level professions." The rationale provided for this provision included in part that the "Provision of health care services in the future is likely to be provided, to an increasing degree, by professionals who are multi- skilled." Provision 12 was that "The NATA should encourage new athletic training education programs to consider aligning themselves in colleges of health-related professions." The rationale for this provision included "Athletic training is an allied health profession”; “... traditional professional preparation programs for physical educators are becoming less financially and politically viable”; “The market for physical educators never rebounded after the drastic cutbacks of the 1970s”; “...athletic trainers are now educated in a manner more consistent with other health professionals than with physical educators"; and "The resources needed to educate athletic trainers exist in abundance in educational units designed to prepare other health professionals.” These provisions have put increasing pressure on athletic training educators to pursue possible linkages with the allied health professions. Moreover, they should motivate kinesiology administrators to consider if kinesiology remains a viable and suitable academic home for accredited ATEPs.

\section{TABLE 5 IS OMITTED FROM THIS FORMATTED DOCUMENT}

\section{The Current State of Athletic Training Education}

Another key provision of the NATA's Education Council was that “The NATA should work with the NATABOC to institute a requirement, to take effect in 2004, that in order to be eligible for NATABOC certification, all candidates must possess a baccalaureate degree and have 
successfully completed a CAAHEP accredited entry-level athletic training education program.” This provision effectively eliminated what had been a second route to certification - the internship route - and has resulted in a proliferation of accredited athletic training education programs. As of July, 2006, 352 entry-level undergraduate programs and 15 entry-level graduate programs were accredited by CAATE, the current recognized accrediting agency for ATEPs. In addition, 13 post-certification graduate programs are accredited by the NATA, and as previously mentioned at least a dozen universities have tailored doctoral-level programs for certified athletic trainers.

The current curriculum requirements for an accredited ATEP have evolved from the two courses required in the 1959 model to an almost staggering list of entry-level subject matter areas (Table 6). In the current clinical education model, students are required to participate in a minimum of 2 years of academic clinical education, and using an outcomes-based approach, students are instructed and evaluated by certified athletic trainers and physicians who are Approved Clinical Instructors (www.nataec.org). The clinical education of athletic training students occurs in colleges/universities, industrial settings, secondary schools, hospitals, professional and Olympic sports, clinics, and other settings that might employ a certified athletic trainer. In fact, the settings in which athletic trainers practice have expanded dramatically from the scholastic, collegiate, and professional sport settings to include sports medicine clinics, industry, hospitals, the military, and others (Table 7). A recent graduate's description of his job setting aptly illustrates how practice settings have changed from those occupied by the original physical education/health teacher-athletic trainer (Table 8). A comprehensive historical perspective of the development and evolution of clinical education in the medical and allied health professions (including athletic training) has been published by Weidner and Henning (2002).

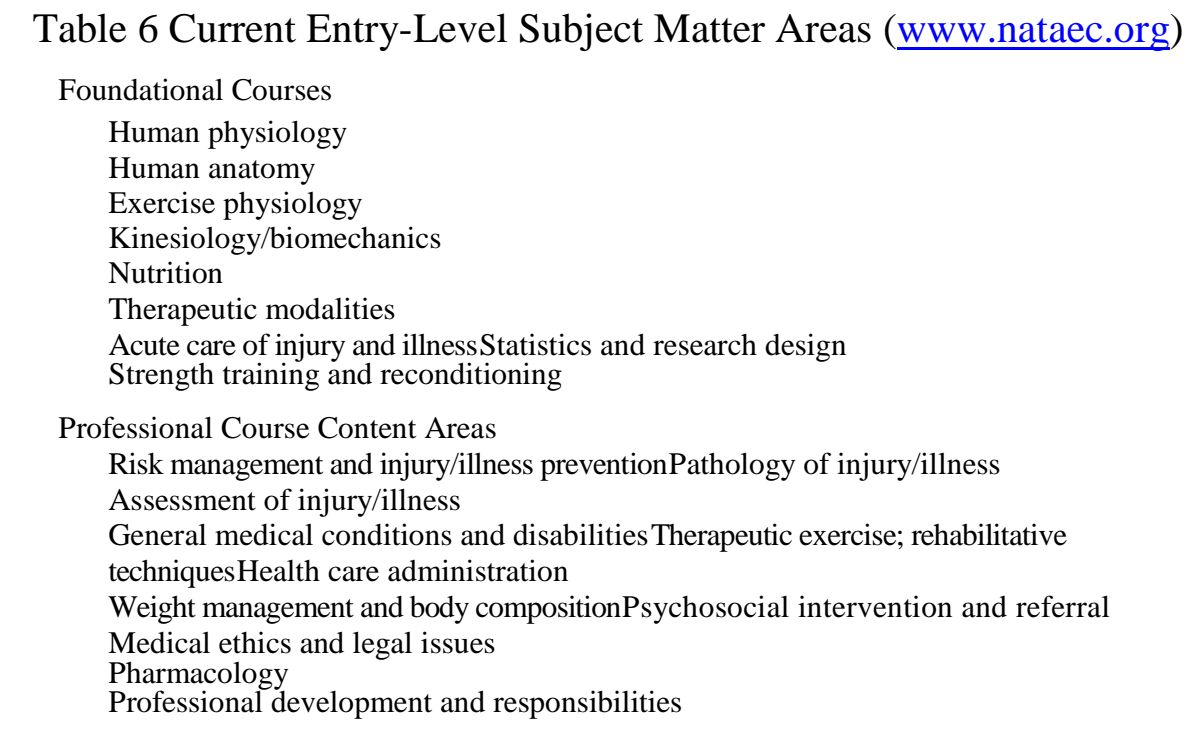

Table 7 Primary Practice Settings (www.nata.org/membership July 2006)

High School: $15.76 \%$

College/University: 19.53\% Professional Sports: $10.52 \%$ Sports

Medicine Clinics: 18.29\%Clinical/Industrial: 4.27\% Hospital: 3.45\% 
Table 8 Position Description of a 2005 University of North Carolina at Greensboro Graduate of the Entry-Level MS Program in Athletic Training

"I ended up taking a job with NovaCare Rehabilitation, where I am working with a power company called ComEd."

"I am working with ComEds safety team presenting educational classes on soft tissue injury prevention.”

"This company also has training centers where, once I am done with the educational classes, I will be acting as a clinical ATC.”

"I will be treating injuries on site and coordinating with the companys nurses."

The latest challenge faced by kinesiology administrators is the NATA mandate for a degree in athletic training no later than the 2014-2015 academic year (NATA News, 2006). This NATA Board of Directors mandate emanated from the recent work of the NATA Educational Degree Task Force, which was charged in part with reviewing the feasibility of requiring a graduate degree as the entry-level requirement for the profession (similar to evolutionary trends in other health care professions such as physical therapy, occupational therapy, speech-languagepathology, etc.). The three primary recommendations of the Task Force were (1) "No later than the 2014-2015 academic year, individuals entering the profession must have a degree in athletic training," (2) "The minimum entry point into this profession will continue to be at the baccalaureate level,” and (3) “The NATA-accredited post-professional master's degree programs should become the foundation of post-professional athletic training education.”

\section{Does Athletic Training Belong in Kinesiology?}

The definition of kinesiology and the programs that comprise the discipline was the theme of the 2006 meeting of the American Academy of Kinesiology and Physical Education, and remains under debate. One definition that has particular relevance to the topic of this paper can be found in the text, Introduction to Kinesiology and Physical Education-2nd Edition (Hoffman, 2005), which states "Kinesiology is a discipline or body of knowledge that focuses on physical activity.” The web page of the National Athletic Trainers' Association (http://www.nata.org) states: "Certified athletic trainers are health care professionals who specialize in preventing, recognizing, managing, and rehabilitating injuries that result from physical activity.” The underlying focus of both definitions is physical activity, and this should generate a number of logical linkages in the curriculum and research foci of kinesiology and athletic training. My own research interests in the disparate rate of injury to the anterior cruciate ligament (ACL) in physically active females in comparison to their male counterparts serves as an excellent example. Table 9

Table 9 Examples of Athletic Training/Kinesiology Linkages Using the Anterior Cruciate Ligament (ACL) Injury Model

\section{Kinesiology Program, Course, ACL Issue or Laboratory}

Access of girls to organized youth sport Impact of Title IX on ACL injuries

Philosophy/history of physical activity

Sociology of physical activity

Limb alignment issues

Biomechanics of physical activity

Laxity/neuromuscular response

Sex hormones, laxity, and injury risk

Surgery and restoration of function

Biomechanics and motor development

Physiology of physical activity

Motor behavior and pedagogy

Rehabilitation compliance

Sport and exercise psychology 
presents several of the potential predisposing factors to ACL injury, and the surgery and rehabilitation that is associated with the injury. Matched with each of these factors is what could be a program, course, or research laboratory within a typical unit of kinesiology. Our current $\mathrm{NIH}$-funded research program encompasses faculty expertise in athletic training and sports medicine, exercise physiology, biomechanics, and other fields such as public health (biostatistics), endocrinology, and orthopedics and rehabilitation.

Physical education can unquestionably take credit for providing opportunities to athletic training professional education and enabling it to reach the stature it now enjoys. That said, a strong rationale can certainly be made for ATEPs to be aligned with academic units of allied health, health sciences, or medicine. Academic leaders of institutions with accredited ATEPs, or who aspire to launch these programs, are faced with deciding if athletic training belongs in allied health or kinesiology. It is my opinion that ATEPs can exist, and even fllourish, within units of kinesiology.

\section{Challenges Facing Kinesiology Administrators}

Leaders of academic units of kinesiology face several challenges in offering and retaining accredited ATEPs. Among these challenges are finding qualified faculty, allocation or reallocation of resources to meet the growing demands of the accreditation process, modification of kinesiology core requirements, and most recently, seeking approval to offer a degree in athletic training.

\section{Finding Qualified Faculty}

Perhaps first and foremost is the challenge of finding qualified and experienced faculty to direct the ATEP (Perrin, 2005). The proliferation of ATEPs (352 and growing) has outpaced the preparation and professional development of doctoral-trained athletic training faculty. The consequence is that freshly minted terminal degree athletic trainers are being employed as ATEP program directors. The demands of administering an accredited ATEP combined with the requirements for promotion and tenure place young faculty in a very tenuous situation. Indeed, I can think of no other academic discipline where junior faculty are placed in administrative roles of this magnitude while at the same time being expected to launch a scholarly agenda worthy of promotion and tenure. Alternative strategies may be indicated, and perhaps kinesiology administrators should consider non-tenure track academic appointments for ATEP program directors. For example, the School of Health and Human Performance at the University of North Carolina at Greensboro (UNCG) has created the Academic Professional Track (http://www.uncg.edu/hhp/AP\%20Track. doc), which is outside of the tenure track but carries the same academic ranks as the tenure track. This track was created to recognize the specialized and essential roles played by various faculty across the school.

If the appointment is within the tenure track, ideally the program director's scholarly agenda would be related to the roles and responsibilities of directing an ATEP (e.g., pedagogical strategies, instructional technology, or the "scholarship of teaching”). Differential work assignments might also be considered and applied for faculty carrying heavy administrative or supervisory loads, such as athletic training program directors and clinical coordinators. The UNCG Promotion and Tenure Guidelines (http://www.uncg.edu/hhp/guidelines.doc) include a fourth category, Directed Professional Activity, in addition to teaching, research, and service. 
This category is defined as “....assigned University activity whose contribution is sufficiently distinctive that its significance is diminished when embedded in either of the three categories of teaching, research and creative activity, and service.” The faculty member, department head, and dean must discuss and agree on the faculty member's involvement in directed professional activity, and how this is evaluated and weighed for promotion and tenure. Suffice it to say, under ideal circumstances, only seasoned, tenured faculty members would be appointed to administer ATEPs. The appointment of junior faculty to these roles seems a recipe for failure.

\section{Allocation or Reallocation of Resources}

At one time an ATEP could be offered by essentially one kinesiology athletic training faculty member who directed the program and taught the required coursework. In many cases this individual even served as the institution's head athletic trainer. The rigorous athletic training accreditation process now requires additional resources that are consistent with other allied health professions (e.g., physical therapy, occupational therapy, speech-language pathology, etc.). These resources typically include a qualified program director, one or more additional athletic training faculty, a clinical coordinator, and approved clinical instructors (ACIs). (The ACIs are usually clinical athletic trainers who are athletic department staff members or employees at off-campus affiliated clinical settings). In the face of recent budget cuts and limited resources in higher education, these increasing needs of the accredited ATEP are especially challenging for the kinesiology administrator. Nevertheless, to offer an accredited ATEP requires additional resources, which can cause resentment among other members of the kinesiology faculty. Accordingly, kinesiology administrators and faculty should carefully consider the resource implications before deciding to offer an accredited ATEP.

\section{Modification of Kinesiology Core Requirements}

The academic core of athletic training has expanded from what could be addressed in two courses (basic and advanced athletic training) to the current subject matter presented in Table 6 . Consistent with other professional preparation programs in the allied health professions, these curriculum requirements leave little room for elective coursework or other courses that might be defined as the core content of kinesiology. Indeed, most other allied health professions now require an entry- level master's degree or clinical doctorate for professional practice. Had the NATA Educational Degree Task Force recommended an entry-level master's degree as the minimum entry point into the profession, kinesiology would have become an ideal undergraduate major for students interested in pursing athletic training. In the meantime, kinesiology faculty and administrators interested in offering and/or retaining ATEPs must realize that it is no longer feasible to require athletic training students to complete the traditional core content of kinesiology while at the same time completing the requirements for an accredited ATEP (at least in 4 years).

\section{A Degree in Athletic Training}

As mentioned previously, the NATA Board of Directors adopted the Educational Degree Task Force recommendation that no later than the 2014-2015 academic year, individuals entering the profession must have a degree in athletic training (NATA News, 2006). The NATA's rationale for a degree in athletic training is:

- Assures professional preparation;

- Produces better prepared entry-level professionals; 
- Provides an easily identifiable method to determine academic preparation and qualification;

- Enhances professional and academic recognition and standing; and

- Strengthens legislative, revenue, and reimbursement initiatives.

The matter of the degree in athletic training is addressed in a 2006 newsletter of the Joint Review Committee on Athletic Training Education (http://www.jrcat. org/newsletter/winter_06.pdf), which states that the Commission on Accreditation of Athletic Training Education has agreed that "....a degree in Athletic Training is essential for the appropriate recognition of the education of Athletic Trainers....” The update further explains that CAATE will develop an Ad Hoc Committee in 2006 that “....will work closely with the NATA, Athletic Training educators, and university/college administrators to develop a plan for implementation of this professional standard.” Further information is currently unavailable on the CAATE website.

The requirement for a degree in athletic training creates a time-consuming task for kinesiology administrators and ATEP program directors. Nevertheless, the transition to a degree in athletic training should not be insurmountable for kinesiology programs interested in retaining an accredited ATEP. It is not uncommon for a single department within a college or school to offer multiple degree programs. Moreover, the NATA mandate does not require "departmentalization" of athletic training to offer a degree in the discipline.

\section{Summary}

Athletic training was spawned from physical education, but has evolved into a recognized health care profession with its own accreditation process. A clear case can be made for the transition of athletic training to academic units of allied health, yet a majority of the accredited ATEPs continue to be offered by departments of kinesiology or other non-allied health care units. Athletic training can continue to exist and even flourish within units of kinesiology provided the academic leaders and faculty of these units are willing to adapt to the increasingly rigid accreditation standards under which ATEPs must operate. This adaptation may require academic leaders and faculty of kinesiology to rethink the academic core of the discipline and the relationship between kinesiology and the professional discipline of athletic training. Likewise, it may provide opportunities for programs housed in kinesiology to work collaboratively with programs of health-related professions on their respective campuses.

\section{Acknowledgments}

I thank Kevin M. Guskiewicz, PhD, ATC, and Jolene M. Henning, EdD, ATC, for their critical review of the manuscript and constructive suggestions for improvement.

\section{References}

Arnold, B.L., Gansneder, B.M., \& Perrin, D.H. (2005). Research methods in athletic training. Philadelphia: F.A. Davis Company.

Charles-Liscombe, B.C. (2007). Predicting academic role strain among athletic training educators. Unpublished dissertation, University of North Carolina at Greensboro, Greensboro, NC.

Delforge, G.D., \& Behnke, R.S . (1999) . The history and evolution of athletic training education in the United States. Journal of Athletic Training, 34, 53-61.

Educational Degree Task Force Sets Path for Future (2006). NATA News, March, 12. Hoffman, S .J. (2005). Introduction to kinesiology—2nd ed. Champaign, IL: Human Kinetics. 
Miller, S.J. (1999). Approval of athletic training curriculums at colleges and universities. Journal of Athletic Training, 34, 62-63. (Reprinted from the Journal of the National Athletic Trainers' Association, 1970, vol. 5, no. 2).

NATA Education Task Force (1997). Recommendations to reform athletic training education. NATA News, February, 16-24.

Perrin, D.H. (2005). Leadership in the academy: junior faculty as program directors. Journal of Athletic Training, 40, 258-259.

Weidner, T.G., \& Henning, J.M. (2002). Historical perspective of athletic training clinical education. Journal of Athletic Training, 37, S222-S228. 